\title{
Heterologous expression of a Glyoxalase I gene from sugarcane confers tolerance to several environmental stresses in bacteria
}

\author{
Qibin Wu $^{1}$, Shiwu Gao ${ }^{1}$, Yong-Bao Pan ${ }^{2}$, Yachun Su ${ }^{1}$, Michael P. Grisham ${ }^{2}$, Jinlong Guo ${ }^{1}$, Liping Xu ${ }^{\text {Corresp. }}$ \\ 1, Youxiong Que ${ }^{\text {Corresp. } 1}$ \\ 1 Fujian Agriculture and Forestry University, Key Laboratory of Sugarcane Biology and Genetic Breeding, Fuzhou, Fujian, China \\ 2 USDA-ARS, Sugarcane Research Unit, Houma, LA, USA \\ Corresponding Authors: Liping Xu, Youxiong Que \\ Email address: xIpmail@126.com, queyouxiong@126.com
}

Glyoxalase I belongs to the glyoxalase system that detoxifies methylglyoxal (MG), a cytotoxic by-product produced mainly from triose phosphates. The concentration of MG increases rapidly under stress conditions. In this study, a novel glyoxalase I gene, designated as SoGlol was identified from sugarcane. SoGlol had a size of 1,091 bp with one open reading frame (ORF) of 885 bp encoding a protein of 294 amino acids. SoGlol was predicted as a $\mathrm{Ni}^{2+}$-dependent GLOI protein with two typical glyoxalase domains at positions 28-149 and 159-283, respectively. SoGlol was cloned into an expression plasmid vector, and the His-tagged SoGlol protein produced in Escherichia coli was about 51 kDa. The recombinant $E$. coli cells expressing SoGlol compared to the control grew faster and tolerated higher concentrations of $\mathrm{NaCl}, \mathrm{CuCl}_{2}, \mathrm{CdCl}_{2}$, or $\mathrm{ZnSO}_{4}$. SoGlol ubiquitously expressed in various sugarcane tissues. The expression was up-regulated under the stress of $\mathrm{NaCl}, \mathrm{CuCl}_{2}, \mathrm{CdCl}_{2}, \mathrm{ZnSO}_{4}$, as well as under simulated pathogen stress conditions upon exposure to salicylic acid (SA), methyl jasmonate (MeJA), or abscisic acid (ABA). SoGlol activity steadily increased when sugarcane was subjected to $\mathrm{NaCl}, \mathrm{CuCl}_{2}, \mathrm{CdCl}_{2}$, or $\mathrm{ZnSO}_{4}$ stress. Sub-cellular observations indicated that the SoGlol protein was located in both cytosol and nucleus. These results suggest that the SoGlol gene may play an important role in sugarcane's response to various biotic and abiotic stresses. 


\section{Heterologous expression of a Glyoxalase I gene from sugarcane confers}

\section{2 tolerance to several environmental stresses in bacteria}

3 Qibin Wu' ${ }^{1}$, Shiwu Gao', Yong-Bao Pan ${ }^{2}$, Yachun Su${ }^{1}$, Michael P. Grisham ${ }^{2}$, Jinlong Guo ${ }^{1}$, 4 Liping $\mathrm{Xu}^{1^{*}}$, and Youxiong Que ${ }^{1^{*}}$

$5{ }^{1}$ Key Laboratory of Sugarcane Biology and Genetic Breeding, Fujian Agriculture and Forestry 6 University, Ministry of Agriculture, Fuzhou 350002, China

$7 \quad{ }^{2}$ USDA-ARS, SEA, Sugarcane Research Unit, Houma, LA 70360, USA

8 *Correspondences: Youxiong Que and Liping $\mathrm{Xu}$, Key Laboratory of Sugarcane Biology and 9 Genetic Breeding, Fujian Agriculture and Forestry University, Ministry of Agriculture, No. 15 10 Shangxia Dian Road, Cangshan District, Fuzhou city, Fujian Province, 350000, P.R. China. E11 mails: queyouxiong@,126.com, xlpmail@,126.com

\section{Abstract}

Glyoxalase I belongs to the glyoxalase system that detoxifies methylglyoxal (MG), a cytotoxic by-product produced mainly from triose phosphates. The concentration of MG increases rapidly under stress conditions. In this study, a novel glyoxalase I gene, designated as SoGloI was identified from sugarcane. SoGloI had a size of 1,091 bp with one open reading frame (ORF) of 885 bp encoding a protein of 294 amino acids. SoGloI was predicted as a $\mathrm{Ni}^{2+}$-dependent GloI protein with two typical glyoxalase domains at positions 28-149 and 159-283, respectively. SoGloI was cloned into an expression plasmid vector, and the Trx-His-S-tag SoGloI protein produced in Escherichia coli was about $51 \mathrm{kDa}$. The recombinant E. coli cells expressing SoGloI compared to the control grew faster and tolerated higher concentrations of $\mathrm{NaCl}, \mathrm{CuCl}_{2}, \mathrm{CdCl}_{2}$, or $\mathrm{ZnSO}_{4}$. SoGloI ubiquitously expressed in various sugarcane tissues. The expression was upregulated under the treatments of $\mathrm{NaCl}, \mathrm{CuCl}_{2}, \mathrm{CdCl}_{2}, \mathrm{ZnSO}_{4}$ and abscisic acid (ABA), or under simulated biotic stress conditions upon exposure to salicylic acid (SA) and methyl jasmonate (MeJA). SoGloI activity steadily increased when sugarcane was subjected to $\mathrm{NaCl}, \mathrm{CuCl}_{2}, \mathrm{CdCl}_{2}$, or $\mathrm{ZnSO}_{4}$ treatments. Sub-cellular observations indicated that the SoGloI protein was located in both cytosol and nucleus. These results suggest that the SoGloI gene may play an important role in sugarcane's response to various biotic and abiotic stresses. 


\section{INTRODUCTION}

Ubiquitously occurring in nature, the glyoxalase pathway involves a two-step catalytic reaction. In the first step, glyoxalase I (GLOI, lactoylglutathione lyase; EC 4.4.1.5) catalyzes the isomerization of hemithioacetal formed spontaneously between methylglyoxal (MG) and reduces glutathione (GSH) to S-D-lactoylglutathione (S-LG) (Thornalley, 1993). In the second step, SLG is hydrolyzed by glyoxalase II (GLOII, hydroxyacylglutathione hydrolase; EC 3.1.2.6) to produce GSH and D-lactate (Yadav et al., 2005). Under normal physiological conditions, MG is produced primarily through glycolysis at the triose-phosphate step (Phillips \& Thornalley, 1993), and to a much lesser extent, through catabolism of amino acids (threonine and glycine) and acetone (Yadav et al., 2005, 2007). Under abiotic stresses, however, the concentration of MG in plants can significantly increase by 2-6 folds (Yadav et al., 2005). The high-level accumulation of MG is toxic to cells, as it can react with DNA to form modified guanylate residues (Papoulis, Al-Abed \& Bucala, 1995). MG also can react with proteins to form glycosylamine derivatives of arginine, lysine and hemithioacetal with cysteine residues (Lo et al., 1994). Apart from the direct effect of MG, its intermediate compound S-LG, a substrate for glyoxalase II, is also cytotoxic at higher concentrations by inhibiting DNA synthesis (Thornalley, 1996). Therefore, glutathionebased detoxification of harmful metabolites is one of the main roles of both glyoxalase enzymes (Thornalley, 1990).

The glyoxalase I enzyme is broadly categorized into $\mathrm{Zn}^{2+}$-or $\mathrm{Ni}^{2+}$-dependent class of metal activation. Previous studies have been showed that the $\mathrm{Zn}^{2+}$-dependent GLOI enzymes are thought to be of eukaryotic origin (Frickel et al., 2001; Ridderström et al., 1996), while $\mathrm{Ni}^{2+}$ dependent GLOI enzymes are thought to be of prokaryotic origin (Sukdeo et al., 2004). The coexistence of both $\mathrm{Zn}^{2+}$-dependent and $\mathrm{Ni}^{2+}$-dependent GLOI enzymes in Pseudomonas aeruginosa (Sukdeo et al., 2007) and the characterization of a $\mathrm{Ni}^{2+}$-dependent GLOI enzyme from rice (Mustafiz et al., 2014) have led to the discouragement of the view that $\mathrm{Zn}^{2+}$-dependent GLO I belongs to eukaryotes and $\mathrm{Ni}^{2+}$-dependent GLOI exists only in prokaryotes (Jain et al., 2016). In plants, the metal specificity of each member of the GLOI family is an important determinant of its catalytic efficiency (Kaur et al., 2017; Mustafiz et al., 2014).

The glyoxalase system has been widely studied in animals and microbes (Price \& Knight, 2009; Thornalley, 2003). Some studies have suggested that the glyoxalase system is associated with clinical disorders, such as cancer and diabetes (Price \& Knight, 2009; Thornalley, 2003). To date, GLOI has been cloned and characterized from several plant species, including Oryza sativa (Kaur et al., 2017; Mustafiz et al., 2014; Usui et al., 2001; Zeng et al., 2016), Glycine max (Skipsey et al., 2000), Zea mays (Chen et al., 2004), Triticum aestivum (Lin et al., 2010), Triticum medicata (Johansen, Svendsen \& Rasmussen, 2000), Brassica juncea (Veena, Reddy \& 
67

68

69

70

71

72

73

74

75

76

77

78

79

80

81

82

83

84

85

86

87

88

89

90

91

92

93

94

95

96

97

98

99

100

101

102

103

104

105

Sopory, 1999), Solanum lycopersicum (Espartero, Sanchez-Aguayo \& Pardo, 1995), Allium cepa (Hossain \& Fujita, 2009), and Beta vulgaris M14 (Wu et al., 2013a). Studies have shown that GLOI activity is up-regulated in response to light and phytohormones (Chakravary \& Sopory, 1988; Deswal \& Sopory, 1999; Sethi, Guha-Mukherjee \& Basu, 1988). Moreover, enzyme activity and transcription of GLOI are up-regulated in response to abiotic and biotic stresses, such as $\mathrm{NaCl}$, heavy metals, mannitol, MG, abscisic acid or pathogen attack (Espartero, SanchezAguayo \& Pardo, 1995; Ghosh and Islam, 2016; Jain et al., 2016; Kaur et al., 2017; Lin et al., 2010; Mustafiz et al., 2011; Mustafiz et al., 2014; Singla-Pareek, Reddy \& Sopory, 2003; SinglaPareek et al., 2006; Veena, Reddy \& Sopory, 1999). Other GLOI genes such as Gly I, GLX1, BvM14-glyoxalase I, TaGly I, OsGLYI-11.2, OsGly I, and OsGlyI-8 isolated from B. juncea (Veena, Reddy \& Sopory, 1999), S. lycopersicum (Espartero, Sanchez-Aguayo \& Pardo, 1995), B. vulgaris M14 (Wu et al., 2013a), T. aestivum (Lin et al., 2010), and rice (Kaur et al., 2017; Mustafiz et al., 2014; Zeng et al., 2016) respectively, have been associated with significant tolerance to salt stress. Singla-Pareek et al. (2006) have shown that Gly I from B. Juncea enhances the tolerance to heavy metals, such as zinc, cadmium or lead. Lin et al. (2010) also have shown that TaGly I was up-regulated under $\mathrm{ZnCl}_{2}$ treatment. Mustafiz et al. (2011) reported a high level of stress inducibility of $\mathrm{Ni}^{2+}$-dependent GlxI encoding AtGLYI3 and AtGLYI6 in response to salt, drought, wounding, cold and heat treatments in both Arabidopsis thaliana roots and shoots, whereas $\mathrm{Zn}^{2+}$-dependent GlxI encoding AtGLYI2 was found to be heat inducible. Transgenic tobacco plants over-expressing GlyI were highly tolerant to $\mathrm{MG}$, salt, or zinc and were able to grow, flower, and produce viable seeds (Singla-Pareek, Reddy \& Sopory, 2003; Singla-Pareek et al., 2006; Veena, Reddy \& Sopory, 1999). Zeng et al. (2016) reported that OsGly $I$ was markedly up-regulated in response to $\mathrm{NaCl}, \mathrm{ZnCl}_{2}$ and mannitol in rice seedlings. Compared to the wild-type plants, the OsGly I-overexpression transgenic rice lines showed increased glyoxalase enzyme activity, decreased $\mathrm{MG}$ level, improved tolerance to $\mathrm{NaCl}, \mathrm{ZnCl}_{2}$ and mannitol, and produced higher rates of seed setting and higher yields. Another $\mathrm{Ni}^{2+}$ dependent $G l x I$ gene, $O s G L Y I-11.2$, was found to be highly stress inducible amongst the rice glyoxalase family (Mustafiz et al., 2014). Similarly, $\mathrm{Ni}^{2+}$-dependent GlxI genes from Arabidopsis were found to be more responsive to various stress treatments compared to $\mathrm{Zn}^{2+}$-dependent GlxI genes (Mustafiz et al., 2011). All these findings suggest that the GLOI genes may play an important role in response to stresses.

Sugarcane (Saccharum spp. hybrids) is a cash crop mainly used for sugar, biofuel and other food industries such as industrial alcohol in tropical and subtropical regions. It is one of the world's largest crops. According to FAO, sugarcane was cultivated in 101 countries on about 26.1 million hectares of land in 2012 (Que et al., 2014). However, the yields of sugarcane are often influenced by many diseases and various environmental stresses, such as smut, rust, ratoon stunting disease (RSD), salt, heavy metal and drought. Sugarcane is reportedly susceptible to salt and shows toxicity symptoms, low sprout emergence, nutritional imbalance, and overall biomass reduction (Akhtar, Wahid \& Rasul, 2003; Plaut, Meinzer \& Federman, 2000; Wahid, Rao \& 
106 Rasul, 1997). Though sugarcane plants can overcome a short period of water deficit during the

107 late, sucrose accumulating growth stage, an extended period of drought can cause a significant 108 loss in cane and sugar yields (Begcy et al., 2012). RSD causes significant yield losses, 12\% $10937 \%$ under normal conditions and up to $60 \%$ under drought conditions. Moreover, it may also 110 lead to variety deterioration (Bailey et al., 1997; James 1996; Que et al., 2008). Sugarcane smut 111 also causes serious losses in cane and sugar yields (Hoy et al., 1986; Padmanaban, Alexander \& 112 Shanmugan, 1998; Que et al., 2012).

113 In our previous study, we constructed a sugarcane cDNA library from Sporisorium 114 scitamineum-infected buds (Wu et al., 2013b). An expressed sequence tag of 613 bp (GenBank 115 Accession Number: CA140600.1) had a high similarity to the GLOI gene of Zea mays (GenBank 116 Accession Number: EU966885.1) (Wu et al., 2013b). To study stress response of GLOI in 117 sugarcane, we cloned the entire sugarcane Glyoxalase I gene, designated as SoGloI. We 118 determined the sub-cellular location of the SoGloI's protein using tobacco protoplasts and 119 investigated growth patterns of Escherichia coli Rosetta cells producing the SoGloI recombinant 120 protein in response to salt and heavy metal ion stresses. We also assessed SoGloI expression and 121 glyoxalase I enzyme in sugarcane in response to simulated biotic and abiotic stresses. The results 122 provided valuable information for the improvement of stress resistance in sugarcane.

\section{MATERIALS \& METHODS}

\section{Plant material}

125 Sugarcane genotype YCE 05-179 was used in this study. Plants were maintained in a genetic 126 nursery at the Key Laboratory of Sugarcane Biology and Genetic Breeding, Ministry of 127 Agriculture, Fujian Agriculture and Forestry University, Fuzhou, China. In addition, tissue 128 culture-derived young, healthy plantlets of YCE 05-179 were also involved in the study.

\section{Cloning of SoGloI gene}

130 A BLAST search of the sugarcane database (taxid: 286192; taxid: 4547; taxid: 128810; taxid: 131 62335) of GenBank (http://www.ncbi.nlm.nih.gov/) was conducted with the sugarcane EST, 132 CA140600.1 (Wu et al., 2013b). Several highly homologous sugarcane ESTs were obtained and 133 aligned. A 1,446 bp cDNA of sugarcane Glo I gene, designated as SoGloI, was assembled using 134 the CAP3 Sequence Assembly Program (http://pbil.univ-lyon1.fr/cap3.php). SoGloI cDNA 135 sequence was amplified in a $25 \mu \mathrm{L}$ reaction mixture on ABI Veriti96 PCR with primers G-F and 136 G-R (Table 1) under a thermal cycling program: $94^{\circ} \mathrm{C}, 4 \mathrm{~min} ; 35$ cycles of $\left(94^{\circ} \mathrm{C}, 1 \mathrm{~min} ; 54^{\circ} \mathrm{C}, 1\right.$ $137 \mathrm{~min} ; 72^{\circ} \mathrm{C}, 1.5 \mathrm{~min}$ ); and $72^{\circ} \mathrm{C}, 10 \mathrm{~min}$. Reaction mixture contained $2.5 \mu \mathrm{L} 10 \times$ PCR buffer (plus $\left.138 \mathrm{Mg}^{2+}\right), 2.5 \mu \mathrm{L}$ dNTPs $(2.5 \mathrm{mM}), 1.0 \mu \mathrm{L}$ first-strand cDNA, $1.0 \mu \mathrm{L}$ each of forward and reverse 139 primers $(10 \mu \mathrm{M})$ and $0.125 \mu \mathrm{L}$ Ex-Taq enzyme $\left(5 \mathrm{U} \cdot \mu \mathrm{L}^{-1}\right)$ (Takara, China). Amplified SoGloI 140 cDNA product was separated through 1\% agarose gel electrophoresis, gel purified using Omega 141 Gel Extraction Kit (Omega, China), and cloned into the PMD 18-T vector (Takara, China). 
142 Putative recombinants were confirmed by PCR, of which six were sequenced (Shenggong Co., 143 Ltd., China).

\section{Bioinformatics analysis}

145 The ORF of the full-length SoGloI was predicted using the ORF Finder program 146 (http:/www.ncbi.nlm.nih.gov/gorf/gorf.html). Molecular weight and isoelectric point was

147 calculated using Compute pI/Mw tool (http://www.expasy.ch/tools/pi_tool.html). Protein domain 148 was predicted using the SMART Program (http://smart.embl-heidelberg.de/). Protein 149 hydrophilicity was analyzed by Protscale Program (http://www.expasy.ch/tools/protscale.html). 150 Prediction of signal peptides and analysis of trans-membrane helix domain were conducted using 151 the SignalP and TMHMM-2.0 Programs (http://www.cbs.dtu.dk/services/). A multiple protein152 sequence alignment was carried out using the DNAMAN ${ }^{\circledR}$ Program (Guo et al., 2012; Liu et al., 153 2010; Su et al., 2013).

154

\section{Expression of SoGloI in field-grown sugarcane plants}

156 Five tissue samples, white young roots, leaf $(+1)$, leaf sheath $(+1)$, buds $\left(6^{\text {th }}-8^{\text {th }}\right.$ from the base), 157 and internodes ( $6^{\text {th }}$ and $7^{\text {th }}$ from the base) were collected from 7- to 8-month-old plants in the 158 field nursery. All samples except buds were cut into small pieces, wrapped up within tinfoil, and 159 immediately flash-frozen in liquid nitrogen. The frozen samples were stored in a $-80^{\circ} \mathrm{C}$ freezer 160 until RNA extraction. Total RNA samples were isolated from the frozen buds using the TRIzol ${ }^{\circledR}$ 161 kit (Invitrogen, USA) according to the manufacturer's instructions. RNA samples were dissolved 162 in diethylpyrocarbonate-treated $\mathrm{H}_{2} \mathrm{O}$. RNA concentration was quantified by measuring 163 absorbance at $\mathrm{OD}_{260}$ and $\mathrm{OD}_{280}$ using Synergy H1 Microplate Reader Multi-Mode (Bio-Tek, 164 USA). RNA quality was also assessed by 1.0\% denaturing agarose gel electrophoreses.

165 First-strand cDNA was synthesized from $1 \mu \mathrm{g}$ RNA in $20 \mu \mathrm{L}$ reaction mixture by reverse 166 transcription PCR (RT-PCR) using the Prime-Script ${ }^{\circledR} 1^{\text {st }}$ Strand cDNA Synthesis Kit (Takara, 167 China) on ABI Veriti96 PCR (ABI, USA). For real-time quantitative PCR (RT-qPCR), a total of $1681 \mu \mathrm{g}$ RNA in $20 \mu \mathrm{L}$ reaction mixtures was used for the first-strand cDNA synthesis using the 169 Prime-Script $^{\circledR}$ RT Reagent Perfect Real Time Kit (Takara, China) on ABI Veriti96 PCR. $170 \mathrm{GAPDH}$ (CA254672) gene was used as the internal control. The primers of GAPDH171 QF/GAPDH-QR were listed in Table 1 (Iskandar et al., 2004; Que et al., 2009).

\section{SoGloI expression in greenhouse-grown sugarcane plantlets under different stress} 173 treatments

174 In the greenhouse, tissue culture-derived 4-month old healthy plantlets were rinsed with agar 175 medium and transplanted into every other column of $46 \mathrm{~mL}$-wells in two 96-well (8 x 12) plastic 176 trays, containing only distilled water. The water was changed every morning. After 10 days, the

177 plantlets were transplanted to $100-\mathrm{mL}$ flat-bottomed glass tubes and subjected to seven different 178 stress treatments in three replicates. Three plantlets of each treatment was treated with the 
179 following solutions: $100 \mu \mathrm{M}$ methyl jasmonate (MeJA, dissolved with $0.1 \%(\mathrm{v} / \mathrm{v})$ ethanol and

$180 \quad 0.05 \%$ (v/v) Tween-20); $5.0 \mathrm{mM}$ salicylic acid (SA, dissolved with $0.05 \%$ (v/v) Tween-20); 100

$181 \mu \mathrm{M}$ abscisic acid (ABA) for 6, 12, and $24 \mathrm{~h}$ (Li et al., 2009; Su et al., 2013); $250 \mathrm{mM} \mathrm{NaCl;} 500$

$182 \mu \mathrm{M} \mathrm{CdCl}_{2} ; 100 \mu \mathrm{M} \mathrm{CuCl}_{2}$; or $100 \mu \mathrm{M} \mathrm{ZnSO}_{4}$ for 12, 24 and $48 \mathrm{~h}$ (Damaj et al., 2010; Guo et al.,

183 2012; Que et al., 2009), respectively. Plantlets grown in distilled water were used as the control.

184 SoGloI expression in response to MeJA, SA, ABA (0, 6, 12, 24 hour-post-treatment or hpt) 185 and $\mathrm{NaCl}, \mathrm{CdCl}_{2}, \mathrm{CuCl}_{2}, \mathrm{ZnSO}_{4}(0,12,24,48 \mathrm{hpt})$ was analyzed by RT-qPCR on a $7500 \mathrm{RT}$ 186 qPCR system (ABI, USA). 25S rRNA (BQ536525) gene was chosen as internal control and. The 187 primers of 25S-QF/25S-QR were listed in Table 1 . The SoGloI-specific primer pair of G-QF/G188 QR was designed by Primer Premier 5.0 software (Premier Biosoft International, CA) (Table 1). 189 RT-qPCR was carried out with FastStart Universal SYBR Green Master (ROX) (Roche, China) 190 in a $25 \mu \mathrm{L}$ volume containing $12.5 \mu \mathrm{L}$ FastStart Universal SYBR Green PCR Master (ROX), 0.5 $191 \mu \mathrm{M}$ of each primer and $1.0 \mu \mathrm{L}$ template $\left(100 \times\right.$ diluted cDNA). RT-qPCR with sterile $\mathrm{dH}_{2} \mathrm{O}$ as 192 template was the control. The RT-qPCR thermal cycle program included 2 min at $50^{\circ} \mathrm{C} ; 10 \mathrm{~min}$ 193 at $95^{\circ} \mathrm{C}$; and 40 cycles of $\left(15 \mathrm{~s}\right.$ at $94^{\circ} \mathrm{C}$ and $1 \mathrm{~min}$ at $\left.60^{\circ} \mathrm{C}\right)$. The reactions were repeated three 194 times for each sample. The $2^{\text {-ddCt }}$ method was used to calculate relative gene expression levels 195 (Livak \& Schmittgen, 2001).

196 Expression of pET32a-SoGloI in E. coli Rosetta Cells (DE3)

197 A SoGloI gene fragment was amplified from the cDNA clone with primers G-32aF/G-32aR 198 (Table 1). The SoGloI PCR fragment was digested with EcoRI and XhoI (NEB, USA) and 199 subsequently sub-cloned into the EcoRI-XhoI sites of pET32a (+) (Guo et al., 2012) to produce 200 pET32a-SoGloI. After sequence verification, the pET32a-SoGloI was transformed into Rosetta 201 Cells (DE3) (Tiangen BioTech Co. Ltd., China). Expression of pET32a-SoGloI was induced in 1 $202 \mathrm{mM}$ isopropyl $\beta$-D-thiogalactoside (IPTG) for $8 \mathrm{~h}$ at $37^{\circ} \mathrm{C}$ and analyzed by sodium dodecyl 203 sulfate-polyacrylamide gel electrophoresis (SDS-PAGE) at 0, 2, 4, and $8 \mathrm{~h}$. Non-transformed 204 (blank) and the vector pET32a-transformed Rosetta cells (control) were used as the controls.

Spot assays were performed to assess the response of pET32a-SoGloI transformed E. coli cells to $\mathrm{NaCl}, \mathrm{CdCl}_{2}, \mathrm{CuCl}_{2}$ or $\mathrm{ZnSO}_{4}$ treatments. When the $E$. coli culture mixture reached $\mathrm{OD}_{600}=$ 0.6, $1 \mathrm{mM}$ IPTG was added into the LB medium and the culture mixture was incubated for $12 \mathrm{~h}$ at $28^{\circ} \mathrm{C}$. Then the cultures were first diluted to $0.6\left(\mathrm{OD}_{600}\right)$, and further diluted to two levels $\left(10^{-3}\right.$ and $10^{-4}$ ) (Guo et al., 2012). Thereafter, $10 \mu \mathrm{L}$ each of the diluted cultures was spotted on LB

210 plates containing $170 \mu \mathrm{g} \cdot \mathrm{mL}^{-1}$ chloramphenicol and $80 \mu \mathrm{g} \cdot \mathrm{mL}^{-1}$ ampicillin, along with each test 211 chemical. The concentrations of the chemicals used were $\mathrm{NaCl}$ at 250,500 and $750 \mathrm{mM}, \mathrm{CdCl}_{2}$

212 at 250,500 and $750 \mu \mathrm{M}, \mathrm{CuCl}_{2}$ at 250,500 and $750 \mu \mathrm{M}$, and $\mathrm{ZnSO}_{4}$ at 250, 500 and $750 \mu \mathrm{M}$, 213 respectively (Guo et al., 2012; Su et al., 2013). All plates were incubated overnight at $37^{\circ} \mathrm{C}$.

\section{Assay of sugarcane glyoxalase I enzyme activity}


215 Entire flash-frozen 4-month old plantlets (100 mg wet weight) were pulverized in liquid $\mathrm{N}_{2}$ in a 216 mortar. Protein was extracted with an extraction buffer containing 0.1 M potassium phosphate 217 buffer (PPB, pH 7.5), 50\% (v/v) glycerol, $16 \mathrm{mM} \mathrm{MgSO}_{4}, 0.2 \mathrm{mM}$ Phenylmethanesulfonyl 218 fluoride (PMSF) and $0.2 \%(\mathrm{v} / \mathrm{v})$ polyvinylpyrrolidone (PVP40). The extract was centrifuged 219 twice at $13,000 \mathrm{rpm}$ at $4^{\circ} \mathrm{C}$ for 30 min to obtain the crude protein extract from the supernatant 220 (Zeng et al., 2016). The supernatant was used as the cytosolic extract for the assessment of 221 glyoxalase activity, and protein concentration was determined by the Bradford method (Bradford. 222 1976) using bovine serum albumin (BSA) as the standard. SoGloI activity assay was carried out 223 following Hossain et al. (2009) and Hasanuzzaman et al. (2011). Briefly, the assay mixture 224 contained $100 \mathrm{mM}$ K-phosphate buffer (PPB, pH 7.0), $15 \mathrm{mM}$ magnesium sulfate, $1.7 \mathrm{mM} \mathrm{GSH}$, 225 and $3.5 \mathrm{mM} \mathrm{MG}$ in a final volume of $0.8 \mathrm{~mL}$. Thioester formation was measured by the increase 226 in absorbance at $240 \mathrm{~nm}$ for $1 \mathrm{~min}$. The enzyme activity was calculated using an extinction 227 coefficient (ع) of $3.37 \mathrm{mM}^{-1} \cdot \mathrm{cm}^{-1}$.

228

229

230

231

232

233

234

235

236

237

238

239

240

241

242

243

244

245

246

247

248

249

250

251

\section{Sub-cellular localization}

The SoGloI gene was sub-cloned into the XcmI/BamHI restriction sites of pCXSN to construct a fusion protein expression vector of $35 \mathrm{~S}:: S o G l o I:$ GFP. The GFP-containing pCXSN vector was a gift of Songbiao Chen, Institute of Biotechnology, Fujian Academy of Agricultural Sciences. The pCXSN-SoGloI recombinant plasmids were transformed into Agrobacterium tumefaciens cells, strain GV 3101 (Chen et al., 2006). The transgenic GV 3101 cells were inoculated into LB medium containing kanamycin $\left(50 \mu \mathrm{g} \cdot \mathrm{mL}^{-1}\right)$ and rifampicin $\left(34 \mu \mathrm{g} \cdot \mathrm{mL}^{-1}\right)$. The culture was incubated overnight at $28^{\circ} \mathrm{C}$ with shaking at $200 \mathrm{rpm}$. The culture was then centrifuged at 5,000 $\mathrm{x} \mathrm{g}$ to harvest the Agrobacterium cells followed by, re-suspension in $10 \mathrm{mM} \mathrm{MgCl}_{2}$ and $10 \mathrm{mM}$ fatty acid methyl ester sulfonate (MES). The concentration of the bacterial suspension was measured and adjusted to $\mathrm{OD}_{600}=0.6$ with Murashige and Skoog (MS) liquid medium supplemented with $200 \mathrm{mM}$ acetosyringone. The resulting culture was incubated at $28^{\circ} \mathrm{C}$ for $3 \mathrm{~h}$ (Yang et al., 2014). Then, $1 \mathrm{~mL}$ of the bacterial culture was infiltrated into 4-week old tobacco leaves with disposable syringes. The injection sites were marked. Injected plants were incubated under a $12 \mathrm{~h}$-light $/ 12 \mathrm{~h}$-dark cycle at $28^{\circ} \mathrm{C}$ for three days (Su et al., 2013). Then, the protoplasts were isolated from well-expanded leaves following the rice protoplast isolation protocol of Chen et al. (2006). Briefly, the leaves were cut into 1-mm strips and placed in a dish containing $12 \mathrm{~mL}$ of $\mathrm{K} 3$ medium ( $3 \mathrm{mM}$ MES, $7 \mathrm{mM} \mathrm{CaCl}, 0.35 \mathrm{M}$ mannitol, $0.7 \mathrm{mM} \mathrm{NaH}_{2} \mathrm{PO}_{4}, 0.35 \mathrm{M}$ sorbitol, $20 \mathrm{mM} \mathrm{KCl}, \mathrm{pH}$ 5.6) supplemented with $0.4 \mathrm{M}$ sucrose, $1.5 \%$ cellulase R-10 (Yakult Honsha, Japan) and 0.3\% macerozyme R-10 (Yakult). The leaf tissue was vacuum-infiltrated for $30 \mathrm{~min}$ at $20 \mathrm{~mm} \mathrm{Hg}$ and digested at room temperature with gentle shaking for $4 \mathrm{~h}$ to produce protoplasts. Then, the $\mathrm{K} 3$ medium was replaced with $12 \mathrm{~mL}$ of W5 solution ( $2 \mathrm{mM}$ MES, 154 $\mathrm{mM} \mathrm{NaCl}, 125 \mathrm{mM} \mathrm{CaCl} 2,5 \mathrm{mM} \mathrm{KCl}, \mathrm{pH} 5.8)$. The protoplasts were collected by centrifugation at $300 \mathrm{x}$ g for $4 \mathrm{~min}$ at $4^{\circ} \mathrm{C}$ and re-suspended in $1 \mathrm{~mL} \mathrm{WI} \mathrm{solution} \mathrm{(4} \mathrm{mM} \mathrm{MES,} \mathrm{0.5} \mathrm{M} \mathrm{mannitol,}$ 
$25220 \mathrm{mM} \mathrm{KCl}, \mathrm{pH}$ 5.7). The sub-cellular location of the SoGloI gene was observed using

253 fluorescence microscopy (Ci-L, Nikon, Japan).

\section{RESULTS}

254

255

256

257

258

259

260

261

262

263

264

265

266

267

268

269

270

271

272

273

274

275

276

277

278

279

280

281

282

283

284

285

286

\section{Sequence analysis of SoGloI}

The full-length of SoGloI (GenBank Accession Number: KC857628) was 1,091 bp with one ORF of 885 bp (Fig. S1). The deduced SoGloI protein had 294 amino acids with a predicted molecular mass of $32.9 \mathrm{kDa}$ and a $\mathrm{pI}$ value of 5.45. Two glyoxalase domains were found, located at 28-149 and 159-283, respectively (Fig. S2). The ProtScale predicted that SoGloI was a hydrophilic protein (Fig. S3). TMHMM Server v.2.0 and SignalP 4.1 Server program predicted that SoGloI was not a trans-membrane protein (Fig. S4, S5).

In order to predict the metal dependency of SoGloI protein, a multiple sequence alignment of SoGloI with other known GloI proteins from Oryza sativa (OsglyI-11.2 and O. Zn-GloI), Arabidopsis thaliana (AtGLYI2, AtGLYI3 and AtGLYI6), Pseudomonas aeruginosa (GloA1, GloA2 and GloA3), Glycine $\max$ (G. Zn-GloI and G. Ni-GloI) and Escherichia coli (GlxI) was done using DNAMAN ${ }^{\circledR}$ (Fig 1). SoGloI shared $87.8 \%, 69.7 \%, 57.3 \%$, and $72.0 \%$ amino acid sequence identities with OsglyI-11.2, AtGLYI3, AtGLYI6, and G. Ni-GloI, respectively (Fig. 1). Extended amino acid sequences (the letters A, B and C in Fig. 1) of OsglyI-11.2, AtGLYI3, AtGLYI6, GloA1, GloA2, G. Ni-GloI, and GlxI were missing in SoGloI, a characteristic of $\mathrm{Ni}^{2+}$ dependent GloI. Contrarily, these extended amino acid sequences were present in AtGLYI2, GloA3, O. Zn-GloI and G. Zn-GloI, which were $\mathrm{Zn}^{2+}$-dependent GloI.

\section{Expression of SoGloI in E. coli}

Upon IPTG induction, the recombinant SoGloI gene expressed well in Rosetta cells (Fig. 2, Lanes 5-8) to yield SoGloI protein that was $51 \mathrm{kDa}$ in size and carried a Trx-His-S-tag of 18.3 $\mathrm{kDa}$. Moreover, gradually increased amounts of SoGloI protein were also observed when the IPTG induction was extended from $2 \mathrm{~h}$ to $8 \mathrm{~h}$.

In the spot assays, SoGloI-expressing Rosetta cells (Fig. 3A-E, Row a) grew more rapidly on LB agar plates containing $\mathrm{NaCl}, \mathrm{CuCl}_{2}, \mathrm{CdCl}_{2}$ or $\mathrm{ZnSO}_{4}$ than control Rosetta cells (pET 32a) (Fig. 3A-E, Row b). Compared to control cells, SoGloI-expressing cells tolerated salt up to 250 $\mathrm{mM}$ (Fig. 3B) as well as heavy metal ions up to $750 \mu \mathrm{M}$ (Fig. 3C-E). Consistently, SoGloIexpressing cells also grew faster than the control cells in LB liquid media containing $250 \mathrm{mM}$ $\mathrm{NaCl}, 750 \mu \mathrm{M} \mathrm{CuCl}_{2}, 750 \mu \mathrm{M} \mathrm{CdCl}_{2}$ or $750 \mu \mathrm{M} \mathrm{ZnSO}_{4}$ (Fig. 4). These results may demonstrate that the recombinant SoGloI protein enhanced the growth of Rosetta cells under stress conditions.

\section{Expression patterns of SoGloI in sugarcane tissues}

RT-qPCR was conducted to detect both tissue-specific and stress-related expression of SoGloI. The SoGloI gene was ubiquitously expressed in five tissues of 7- to 8-month old plants collected 
287 from the field. The highest level was detected in buds, followed by leaves, roots, leaf sheaths, 288 and internodes (Fig. 5A).

289 SoGloI expression patterns in healthy 4-month old plantlets under $\mathrm{NaCl}, \mathrm{CuCl}_{2}, \mathrm{CdCl}_{2}$, $290 \mathrm{ZnSO}_{4}, \mathrm{SA}, \mathrm{MeJA}$, and ABA treatments were shown in Fig. 5B and 5C. Under $\mathrm{NaCl}, \mathrm{CuCl}_{2}$,

$291 \mathrm{CdCl}_{2}$, and $\mathrm{ZnSO}_{4}$ treatments, SoGloI expression was up-regulated steadily from 0 to $48 \mathrm{hpt}$. The 292 peak level of SoGloI expression was about 3.1-, 2.9- 2.8- and 1.9-fold of the level in control, 293 respectively (Fig. 5B). In contrast, under SA and MeJA treatments, SoGloI expression decreased 294 after peaking at $6 \mathrm{hpt}$. The maximum level of SoGloI expression was detected at $6 \mathrm{hpt}$, which 295 was about 2.6- and 2.1-fold of the level in control, respectively (Fig. 5C). Similarly, the peak 296 level of SoGloI expression was detected at $12 \mathrm{hpt}$ under ABA treatments, which was 2.4-fold of 297 the level in control (Fig. 5C). Thus, SoGloI gene has been found to provide tolerance to multiple 298 abiotic stresses.

299 Glyoxalase I activity in sugarcane under $\mathbf{N a C l}, \mathbf{C u C l}_{2}, \mathbf{C d C l}_{\mathbf{2}}$ or $\mathrm{ZnSO}_{\mathbf{4}}$ treatment

300 As shown in Fig. 5D, under $\mathrm{NaCl}, \mathrm{CuCl}_{2}, \mathrm{CdCl}_{2}$, and $\mathrm{ZnSO}_{4}$ treatments, the glyoxalase I activity 301 was increased steadily from 0 to $48 \mathrm{hpt}$. Under a $250 \mathrm{mM} \mathrm{NaCl}$ treatment, the glyoxalase I

302 activity was about 1.8-, 2.2-, and 2.3-fold at 12, 24, and $48 \mathrm{hpt}$ comparing to control, respectively. 303 At $48 \mathrm{hpt}$, the level of glyoxalase I activity reached $0.3230 \mu \mathrm{mol} \cdot \mathrm{min}^{-1} \cdot \mathrm{mg}^{-1}$. Under a $750 \mu \mathrm{M}$ $304 \mathrm{CuCl}_{2}$ treatment, the level of glyoxalase I activity was about 2.0-, 2.7-, and 3.0-fold of the level 305 in control, with $0.4128 \mu \mathrm{mol} \cdot \mathrm{min}^{-1} \cdot \mathrm{mg}^{-1}$ protein produced at $48 \mathrm{hpt}$. Similarly, under a $750 \mu \mathrm{M}$ $306 \mathrm{CdCl}_{2}$ treatment, the glyoxalase I activity was 2.1-, 3.1- and 4.2-fold comparing to control, with

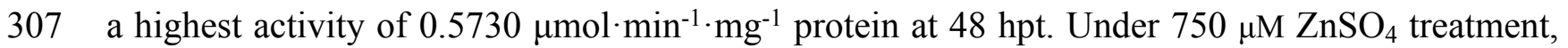
308 the glyoxalase I activity at 12, 24, and 48 hpt was about 1.3-, 2.6-, and 3.1-fold of the level at 0 $309 \mathrm{hpt}$, and $0.2883 \mu \mathrm{mol} \cdot \mathrm{min}^{-1} \cdot \mathrm{mg}^{-1}$ protein produced at $48 \mathrm{hpt}$. Thus, glyoxalase I activity was 310 increased in varying degrees under salt and heavy metal ions stress conditions.

\section{Determination of subcellular localization of ScGloI}

312 To further understand the function of SoGloI gene, its subcellular localization was determined.

313 The SoGloI gene was inserted into a plant expression vector $p C X S N$ between the 35S promoter 314 and GFP. The recombinant pCXSN-SoGloI-GFP construct was then introduced into tobacco 315 leaves through Agrobacterium-mediated transformation. As shown in Fig. 6B, green 316 fluorescence signals were observable in the cytosol and nucleus of both pCXSN-SoGloI-GFP 317 and the pCXSN-GFP transformed tobacco protoplasts.

\section{DISCUSSION}

319 Glyoxalase I functions to detoxify the potent cytotoxic compound MG (Thornalley, 1993). In 320 response to stress conditions, cells undergo active metabolism to produce more MG through 
321 leakages in the glycolysis and TCA cycle (Umea et al., 1994). GlyI, the first enzyme of the

322 glyoxalase system, plays a critical role in controlling MG levels and cytotoxicity (Wu et al., 323 2013a). The GloI gene has been cloned and characterized from several plant species. However, 324 the glyoxalase I gene was never cloned and characterized in sugarcane. In the present study, a 325 length GloI gene, designated as SoGloI, was isolated from a smut-resistant sugarcane cultivar 326 YCE 05-179.

327 The GloI enzyme requires $\mathrm{Ni}^{2+}$ or/and $\mathrm{Zn}^{2+}$ for its catalytic activity (Sukdeo et al., 2004). 328 Sukdeo et al. (2007) reported that Pseudomonas aeruginosa, a gamma proteobacteria, encodes 329 both $\mathrm{Ni}^{2+}$ and $\mathrm{Zn}^{2+}$ forms of the enzyme; GloA1, GloA2 (both Ni binding), and GloA3 ( $\mathrm{Zn}$ 330 binding). Jain et al. (2016) also found three active GLYI enzymes (AtGLYI2, AtGLYI3 and 331 AtGLYI6) belonging to different metal activation classes coexisting in Arabidopsis thaliana. 332 AtGLYI2 was found to be $\mathrm{Zn}^{2+}$-dependent, whereas AtGLYI3 and AtGLYI6 were $\mathrm{Ni}^{2+}$ 333 dependent. $\mathrm{Ni}^{2+}$-dependent $\mathrm{GloI}$ is present as a two-domain protein in all eukaryotes. Among the 334 early branching eukaryotes, algae appears to be the first to encode this gene (Kaur et al., 2013). In this study, a sugarcane SoGloI gene was found to encode two glyoxalase domains as well (Fig. S2). Besides, the multiple protein sequence alignment of SoGloI with those from other species indicated that SoGloI was a $\mathrm{Ni}^{2+}$-dependent enzyme (Fig. 1). The result was similar to OsGLYI11.2 (Mustafiz et al. 2014), who's expression was substrate inducible. However, unlike other eukaryotic $\mathrm{Zn}^{2+}$-dependent glyoxalases, OsGLYI-11.2 is a $\mathrm{Ni}^{2+}$-dependent monomeric enzyme.

Plant glyoxalase system in different tissues plays an important role at various vegetative and reproductive stages (Mustafiz et al., 2011). GLOI gene is required for cell division and proliferation; a higher enzyme activity has been found in rapidly dividing cells of cell suspensions, seedlings, and root tips (Lin et al., 2010; Wu et al., 2013a). In this study, SoGloI was constitutively expressed in various tissues of sugarcane genotype YCE 05-179, with the highest level in buds, followed by leaves, roots, leaf sheaths, and internodes (Fig. 5A).

To date, only a few reports have shown that GLOI gene is associated with disease resistance in plants. For instance, a maize $G l x-I$ gene enhances the host defense against Aspergillus flavus through the detoxification of MG, a major product of A. flavus (Chen et al., 2004). The expression of wheat TaGly I is up-regulated 2.3-fold upon infection by Fusarium graminearum (Lin et al., 2010). In our previous study, SoGloI expression was up-regulated during infection with $S$. scitamineum, the pathogen of sugarcane smut (Wu et al., 2013b). In the present study, we used SA and MeJA to simulate biotic stress. Consistently, under SA and MeJA treatments, the SoGloI expression peaked at $6 \mathrm{hpt}$, when its activity reached 2.6- and 2.1-fold higher than that of the control, respectively (Fig. 5C). These results suggest that SoGloI expression can increase significantly under pathogenic stresses; however, the exact role of SoGloI in pathogenic resistance process needs to be further investigated.

Glyoxalase I genes also have been implicated to enhance plant tolerance to salt stress. The 359 expression of Gly, a glyoxalase I gene of B. juncea, is up-regulated after exposure to a high concentration of salt (Veena, Reddy \& Sopory, 1999). The mRNA and polypeptide levels of 
$360 G L X 1$, a glyoxalase I gene of tomato, increased by two to three folds in roots, internodes and

361 leaves when the plants were treated with $10 \mathrm{~g} / \mathrm{L} \mathrm{NaCl}$ (Espartero, Sanchez-Aguayo \& Pardo,

362

363

364

365

366

367

368

369

370

371

372

373

374

375

376

377

378

379

380

381

382

383

384

385

386

387

388

389

390

391

392

393

394

395

396

397 1995). The expression of two other glyoxalase I genes, BvM14-glyoxalase I of sugar beet (Wu et al., 2013a) and TaGly I of wheat (Lin et al., 2010), also significantly enhanced hosts' tolerance to salt stress. In this study, SoGloI-expressing Rosetta cells grown on agar plates tolerated high concentrations of $\mathrm{NaCl}$ up to $250 \mathrm{mM}$ (Fig. 3B) and grew faster in LB liquid medium containing $250 \mathrm{mM} \mathrm{NaCl}$ (Fig. 4A). SoGloI expression was increased steadily from 0 to $48 \mathrm{hpt}$ in sugarcane under salt stress (Fig. 5B). Under salt stress, glyoxalase I activity also elevated (Fig. 5D). Taken together, the results indicate the expression level of SoGloI can be significantly up-regulated under salt stress; however, more research is needed to reveal the underlying mechanism.

Zinc $\left(\mathrm{Zn}^{2+}\right)$, a micronutrient, is necessary for plant growth, but an excessive amount of $\mathrm{Zn}^{2+}$ can inhibit plant growth (Sun et al., 2006; Zarcinas et al., 2004). A few studies have demonstrated that plant GloI genes enhance host tolerance to $\mathrm{Zn}^{2+}$. Singla-Pareek et al. (2006) showed that $G l y I$ from B. juncea enhanced host $\mathrm{Zn}^{2+}$ tolerance to toxic levels in the transgenic tobacco. The expression of TaGly I, a glyoxalase I gene of T. aestivum, is induced continuously under $20 \mathrm{mM} \mathrm{ZnCl}_{2}$ treatment. Compared to control, the increase in TaGly I expression is nearly 1.5 -fold at $24 \mathrm{~h}$ (Lin et al., 2010). In the present study, SoGloI-expressing E. coli Rosetta cells were able to tolerate high concentrations of $\mathrm{ZnSO}_{4}$ up to $750 \mu \mathrm{M}$ (Fig. 3E) and also grew faster in LB liquid medium containing $750 \mu \mathrm{M} \mathrm{ZnSO}_{4}$ (Fig. 4D).

Consistently, under $\mathrm{ZnSO} 4$ stress, the SoGloI expression in sugarcane was up-regulated steadily from 0 to $48 \mathrm{hpt}$, when its level and enzyme activity were 1.9-fold and 3.1-fold higher than that of the control (Fig. 5B, 5D). These results showed that SoGloI gene can enhance tolerance to excessive zinc stress even in a heterologous host system. Over-expression of glyoxalase I has been shown to confer tolerance to other heavy metals, such as cadmium or lead (Singla-Pareek et al., 2006). The level of expression and activity of SoGloI in E. coli (Fig. 3D, 4C) under $\mathrm{CdCl}_{2}$ treatment (Fig. 5B, 5D) also supported this notion about tolerance to cadmium. Our work further showed that $S o G l o I$ expression and its enzyme activity were increased significantly under $\mathrm{CuCl}_{2}$ treatment (Fig. 5B, 5D). All these findings suggest that SoGloI may be a good candidate gene for engineering to develop heavy metal resistant sugarcane cultivars.

As is known, sugarcane is a polyploidy and aneuploidy crop (Scortecci et al., 2012), in which low transformation efficiency remains one of the major limiting factors on transgenic sugarcane production (DalBianco et al., 2012; Gómez-Merino, Trejo-Téllez \& Sentíes-Herrera, 2014; Scortecci et al., 2012). This has also limited the functional analysis of isolated sugarcane genes; nonetheless, a model plant species (Arabidopsis thaliana, Nicotiana benthamiana or Brachypodium distachyon) with a shorter life cycle and simpler genome can be explored as an alternative host for transforming and assessing the functional properties of isolated sugarcane genes, such as SoGloI. 


\section{CONCLUSIONS}

399 This is the first report on the cloning and characterization of glyoxalase I (SoGloI) gene in 400 sugarcane. We isolated and characterized SoGloI gene and demonstrated the enzyme activity of 401 glyoxalase I protein. We found that SoGloI expression and SoGloI enzymatic activity were 402 elevated significantly when sugarcane tissues were subject to simulated biotic and abiotic stress 403 conditions, such as high concentrations of salt or heavy metal ions. The findings have opened up 404 a new research avenue for sugarcane to grow in polluted or salty environments via genetic 405 engineering and breeding of SoGloI to enhance host resistance.

\section{SUPPLEMENTARY MATERIALS}

407 Figure S1 Nucleotide acid sequences and deduced amino acid sequences of SoGloI obtained 408 by RT-PCR.

409 Figure S2 Domain architecture analysis of SoGloI protein.

410 Figure S3 Hydrophobicity prediction of SoGloI protein.

411 Figure S4 Signal peptides prediction of SoGloI protein.

412 Figure S5 Trans-membrane helix domain prediction of SoGloI protein.

\section{REFERENCES}


414 Akhtar S, Wahid A, Rasul E. 2003. Emergence, growth and nutrient composition of sugarcane

415

416

417

418

419

420

421

422

423

424

425

426

427

428

429

430

431

432

433

434

435

436

437

438

439

440

441

442

443

444

445

446

447

448

449

450

451

452

453

454

sprouts under $\mathrm{NaCl}$ salinity. Biologia Plantarum 46:113-116 DOI 10.1023/a: 1022326604192.

Bailey RA, Bechet GR. 1997. Further evidence of the effects of ratoon stunting disease on production under irrigated and rainfed conditions. In Proceedings of the South African Sugar Technologists' Association 71:97- 101.

Bradford MM. 1976. A rapid and sensitive method for the quantitation of microgram quantities of protein utilizing the principle of protein-dye binding. Anal. Biochem. 72: 248-254.

Begcy K, Mariano ED, Gentile A, Lembke CG, Zingaretti SM, Souza GM, Menossi M. 2012. A novel stress-induced sugarcane gene confers tolerance to drought, salt and oxidative stress in transgenic tobacco plants. PloS One 7:e44697 DOI 10.1371/journal.pone.0044697.

Chakravarty TN, Sopory SK. 1988. Blue light stimulation of cell proliferation and glyoxalase I activity in callus cultures of Amaranthus paniculatus. Plant Science 132:63-69 DOI 10.1016/S0168-9452(97)00264-1.

Chen SB, Tao LZ, Zeng LR, Vega - Sanchez ME, Umemura K, Wang GL. 2006. A highly efficient transient protoplast system for analyzing defence gene expression and protein protein interactions in rice. Molecular Plant Pathology 7:417-427 DOI 10.1111/j.13643703.2006.00346.x.

Chen ZY, Brown RL, Damann KE, Cleveland TE. 2004. Identification of a maize kernel stress-related protein and its effect on aflatoxin accumulation. Phytopathology 94:938-945 DOI 10.1094/PHYTO.2004.94.9.938.

Clelland JD, Thornalley PJ. 1991. S-2-Hydroxyacyl glutathione-derivatives: enzymatic preparation, purification and characterization. Journal of the Chemical Society, Perkin Transactions 1 12:3009-3015 DOI 10.1039/P19910003009.

Dal-Bianco M, Carneiro MS, Hotta CT, Chapola RG, Hoffmann HP, Garcia AAF, Souza GM. 2012. Sugarcane improvement: how far can we go? Current Opinion Biotechnology 23:265-270 DOI 10.1016/j.copbio.2011.09.002.

Damaj MB, Kumpatla SP, Emani C, Beremand PD, Reddy AS, Rathore KS, BuenrostroNava MT, Curtis IS, Thomas TL, Mirkov TE. 2010. Sugarcane DIRIGENT and $O$ methyltransferase promoters confer stem-regulated gene expression in diverse monocots. Planta 231:1439-1458 DOI 10.1007/s00425-010-1138-5.

Deswal R, Sopory SK. 1999. Glyoxalase I from Brassica juncea is a calmodulin stimulated protein. Biochimica et Biophysica Acta 1450:460-467 DOI 10.1016/S0167-4889(99)000476.

Espartero J, Sanchez-Aguayo I, Pardo JM. 1995. Molecular characterization of glyoxalase I from a higher plant: up-regulation by stress. Plant Molecular Biology 29:1223-1233 DOI 10.1007/BF00020464.

Frickel EM, Jemth P, Widersten M, Mannervik B. 2001. Yeast glyoxalase I is a monomeric enzyme with two active sites. J. Biol. Chem. 276: 1845-1849. DOI 10.1074/jbc.M005760200. 
455

456

457

458

459

460

461

462

463

464

465

466

467

468

469

470

471

472

473

474

475

476

477

478

479

480

481

482

483

484

485

486

487

488

489

490

491

492

493

494

495

496

Ghosh A and Islam T. 2016. Genome-wide analysis and expression profiling of glyoxalase gene families in soybean (Glycine max) indicate their development and abiotic stress specific response. BMC Plant Biol. 16: 87. DOI 10.1186/s12870-016-0773-9.

Gómez-Merino FC, Trejo-Téllez LI, Sentíes-Herrera HE. 2014. Sugarcane as a novel biofactory: potentialities and challenges. In Biosystems Engineering: Biofactories for Food Production in the Century XXI. Springer International Publishing. 129-149.

Guo JL, Xu LP, Fang JP, Su YC, Fu HY, Que YX, Xu JS. 2012. A novel dirigent protein gene with highly stem-specific expression from sugarcane, response to drought, salt and oxidative stresses. Plant Cell Report 31:1801-1812 DOI 10.1007/s00299-012-1293-1.

Hasanuzzaman M, Hossain MA, Fujita M. 2011. Nitric oxide modulates antioxidant defense and the methylglyoxal detoxification system and reduces salinity-induced damage of wheat seedlings. Plant Biotechnol. Rep. 5:353-365 DOI 10.1007/s11816-011-0189-9.

Hossain MA, Fujita M. 2009. Purification of glyoxalase I from onion bulbs and molecular cloning of its cDNA. Bioscience, Biotechnology \& Biochemistry. 73:2007-2013 DOI 10.1271/bbb.90194.

Hoy JW, Hollier CA, Fontenot DB, Grelen LB. 1986. Incidence of sugarcane smut in Louisiana and its effects on yield. Plant Disease. 70:59-60.

Iskandar HM, Simpson RS, Casu RE, Bonnett GD, Maclean DJ, Manners JM. 2004. Comparison of reference genes for quantitative real-time polymerase chain reaction analysis of gene expression in sugarcane. Plant Molecular Biology Reporter. 22:325-337 DOI 10.1007/BF02772676.

Jain M, Batth R, Kumari S, Mustafiz A. 2016. Arabidopsis thaliana Contains both $\mathrm{Ni}^{2+}$ and $\mathrm{Zn}^{2+}$ dependent glyoxalase I enzymes and ectopic expression of the latter contributes more towards abiotic stress tolerance in E. coli. PLoS One 11(7): e0159348. DOI 10.1371/journal.pone.0159348.

James G. 1996. A review of ratoon stunting disease. International Sugar Journal 98: 532-545.

Johansen KS, Svendsen I, Rasmussen SK. 2000. Purification and cloning of the two domains glyoxalase I from wheat bran. Plant Science 155:11-20 DOI 10.1016/S01689452(99)00250-2.

Kao KN, Michayluk MR. 1975. Nutritional requirements for growth of Vicia hajastana cells and protoplasts at a very low population density in liquid media. Planta 126:105-110 DOI 10.1007/BF00380613.

Kurz A, Rabbani N, Walter M, Bonin M, Thornalley P, Auburger G, Gispert S. 2011. Alpha-synuclein deficiency leads to increased glyoxalase I expression and glycation stress. Cellular \& Molecular Life Sciences 68:721-733 DOI 10.1007/s00018-010-0483-7.

Kaur C, Vishnoi A, Ariyadasa TU, Bhattacharya A, Singla-Pareek SL, Sopory SK. 2013. Episodes of horizontal gene-transfer and gene-fusion led to co-existence of different metalion specific glyoxalase I. Scientific Reports. 3: 3076. DOI 10.1038/srep03076.

Kaur C, Tripathi AK, Nutan KK, Sharma S, Ghosh A, Tripathi JK, Pareek A, SinglaPareek SL, Sopory SK. 2017. A nuclear-localized rice glyoxalase I enzyme, OsGLYI-8, functions in the detoxification of methylglyoxal in the nucleus. Plant J. 89(3): 565-576. DOI 10.1111/tpj.13407. 
497

498

499

500

501

502

503

504

505

506

507

508

509

510

511

512

513

514

515

516

517

518

519

520

521

522

523

524

525

526

527

528

529

530

531

532

533

534

535

536

537

538

539

Li DM, Staehelin C, Wang WT, Peng SL. 2009. Molecular cloning and characterization of a chitinase-homologous gene from Mikania micrantha infected by Cuscuta campestris. Plant Molecular Biology Reporter 28:90-101 DOI 10.1007/s11105-009-0125-0.

Lin FY, Xu JH, Shi JR, Li HW, Lin B. 2010. Molecular cloning and characterization of a novel glyoxalase I gene TaGly I in wheat (Triticum aestivum L.). Molecular Biology Reports 37:729-735 DOI 10.1007/s11033-009-9578-3.

Liu B, Xue XD, Cui SP, Zhang XY, Han QM, Zhu L, Liang XF, Huang LL, Chen XM. Kang ZS. 2010. Cloning and characterization of a wheat $\beta$-1, 3-glucanase gene induced by the stripe rust pathogen Puccinia striiformis f. sp. tritici. Molecular Biology Reports 37:1045-1052 DOI 10.1007/s11033-009-9823-9.

Livak KJ, Schmittgen TD. 2001. Analysis of relative gene expression data using real-time quantitative PCR and the 2-ddCt method. Methods 25:402-408 DOI 10.1006/meth.2001.1262.

Lo T, Westwood M, McLellan A, Selwood T, Thornalley P. 1994. Binding and modification of proteins by methylglyoxal under physiological conditions: a kinetic and mechanistic study with $\mathrm{N}$-acetylarginine, $\mathrm{N}$-acetylcysteine, and $\mathrm{N}$-acetyl-lysine and bovine serum albumin. Journal of Biological Chemistry 269:32299-32305.

Mustafiz A, Singh AK, Pareek A, Sopory SK, Singla-Pareek SL. 2011. Genome-wide analysis of rice and Arabidopsis identifies two glyoxalase genes that are highly expressed in abiotic stress. Functional \& Integrative Genomics 11:293-305 DOI 10.1007/s10142-0100203-2.

Mustafiz A, Ghosh A, Tripathi AK, Kaur C, Ganguly AK, Bhavesh NS, Tripathi JK, Pareek A, Sopory SK, Singla-Pareek SL. 2014. A unique $\mathrm{Ni}^{2+}$-dependent and methylglyoxal-inducible rice glyoxalase $\mathrm{i}$ possess a single active site and functions in abiotic stress response. Plant J. 78: 951-963. DOI 10.1111/tpj.12521.

Padmanaban P, Alexander KC, Shanmugan N. 1998. Effect of smut on growth and yield parameters of sugarcane. Indian Phytopathology 41:367-369.

Papoulis A, Al-Abed Y, Bucala R. 1995. Identification of N2-(1-carboxyethyl) guanine (CEG) as a guanine advanced glycosylation end product. Biochemistry 34:648-655 DOI 10.1021/bi00002a032.

Phillips SA, Thornalley PJ. 1993. The formation of methylglyoxal from triose phosphates. European Journal of Biochemistry 212: 101-105 DOI 10.1111/j.1432-1033.1993.tb17638.x.

Plaut Z, Meinzer FC, Federman E. 2000. Leaf development, transpiration and ion uptake and distribution in sugarcane cultivars grown under salinity. Plant and Soil 218:59-69 DOI 10.1023/a: 1014996229436.

Price CL, Knight SC. 2009. Methylglyoxal: possible link between hyperglycaemia and immune suppression? Trends in Endocrinology \& Metabolism 20:312-317 DOI 10.1016/j.tem.2009.03.010.

Que YX, Xu JS, Xu LP, Gao SJ, Chen RK. 2008. PCR detection for Leifsonia xyli subsp. Xyli, pathogen of the sugarcane ratoon stunting disease. Fujian Journal of Agricultural Sciences 23:364-367.

Que YX, Xu LP, Xu JS, Zhang JS, Zhang MQ, Chen RK. 2009a. Selection of control genes in real-time qPCR analysis of gene expression in sugarcane. Chinese Journal of Tropical Crops 30:274-278. 
540 Que YX, Yang ZX, Xu LP, Chen RK. 2009b. Isolation and identification of differentially

541 expressed genes in sugarcane infected by Ustilago scitaminea. Acta Agronomica Sinica $542 \quad 35: 452-458$.

543 Que YX, Xu LP, Lin JW, Chen RK, Grisham MP. 2012. Molecular variation of Sporisorium 544 scitamineum in Mainland China revealed by RAPD and SRAP markers. Plant Disease 96:1519-1525 DOI 10.1094/PDIS-08-11-0663-RE.

547

Que YX, Xu LP, Wu QB, Liu YF, Ling H, Liu YH, Zhang YY, Guo JL, Su YC, Chen JB, Wang SS, Zhang CG. 2014. Genome sequencing of Sporisorium scitamineum provides insights into the pathogenic mechanisms of sugarcane smut. BMC Genomics 15:996 DOI 10.1186/1471-2164-15-996.

Ridderström M, Mannervik B. 1996. Optimized heterologous expression of the human zinc enzyme glyoxalase I. Biochem J. 314: 463-4677. PMID: 8670058.

Scortecci KC, Creste S, Calsa TJ, Xavier MA, Landell MGA, Figueira A, Benedito VA.

553

554

555

556

557

558

559

560

561

562

563

564

565 2012. Challenges, opportunities and recent advances in sugarcane breeding. In Plant Breeding. In Tech 267-296.

Sethi U, Basu A, Guha-Mukherjee S 1988. Control of cell proliferation and differentiation by regulating polyamine biosynthesis in cultures of Brassica and its correlation with glyoxalase activity. Plant Science 56:167-175 DOI 10.1016/0168-9452(88)90031-3.

Singla-Pareek SL, Reddy MK, Sopory SK. 2003. Genetic engineering of the glyoxalase pathway in tobacco leads to enhanced salinity tolerance. Proceedings of the National Academy of Sciences 100:14672-14677.

Singla-Pareek SL, Yadav SK, Pareek A, Reddy, MK, Sopory SK. 2006. Transgenic tobacco over-expressing glyoxalase pathway enzymes grow and set viable seeds in zinc-spiked soils. Plant Physiology 140:613-623 DOI 10.1104/pp.105.073734.

Skipsey M, Andrews CJ, Townson JK, Jepson I, Edwards R. 2000. Cloning and characterization of glyoxalase I from soybean. Archives of Biochemistry \& Biophysics 374:261-268 DOI 10.1006/abbi.1999.1596.

Su YC, Xu LP, Xue BT, Wu QB, Guo JL, Wu LG, Que YX. 2013. Molecular cloning and characterization of two pathogenesis-related $\beta$-1, 3-glucanase genes ScGluA1 and ScGluD1 from sugarcane infected by Sporisorium scitaminea. Plant Cell Reports 32:1503-1519 DOI 10.1007/s00299-013-1463-9.

Sukdeo N, Clugston SL, Daub E, Honek JF. 2004. Distinct classes of glyoxalase I: metal specificity of the Yersinia pestis, Pseudomonas aeruginosa and Neisseria meningitidis enzymes. Biochem J. 384:111-117. DOI 10.1042/BJ20041006.

Sukdeo N, Honek JF. 2007. Pseudomonas aeruginosa contains multiple glyoxalase I-encoding

576

577

578 genes from both metal activation classes. Biochim. Biophys. Acta-Proteins Proteomics 1774:756-763.

Sun YF, Xie ZM, Li J, Xu JM, Chen ZL, Naidu R. 2006. Assessment of toxicity of heavy metal contaminated soils by the toxicity characteristic leaching procedure. Environmental Geochemistry \& Health 28:73-78 DOI 10.1007/s10653-005-9014-0. 
580

581

582

583

584

585

586

587

588

589

590

591

592

593

594

595

596

597

598

599

600

601

602

603

604

605

606

607

608

609

610

611

612

613

614

615

616

617

618

619

620

621

622

Thornalley PJ. 1990. The glyoxalase system: new developments towards functional characterization of a metabolic pathway fundamental to biological life. Biochemical Journal 269:1-11.

Thornalley PJ. 1993. The glyoxalase system in health and disease. Molecular Aspects of Medicine 14:287-371 DOI 10.1016/0098-2997(93)90002-U.

Thornalley PJ. 1996. Pharmacology of methylglyoxal: formation, modification of proteins and nucleic acids, and enzymatic detoxification-a role in pathogenesis and antiproliferative chemotherapy. General Pharmacology: The Vascular System 27:565-573 DOI 10.1016/0306-3623(95)02054-3.

Thornalley PJ. 2003. Protecting the genome: defense against nucleotide glycation and emerging role of glyoxalase I over-expression in multidrug resistance in cancer chemotherapy. Biochemical Society Transactions 31:1372-1377 DOI 10.1042/bst0311372.

Tuomainen M, Ahonen V, Kärenlampi SO, Schat H, Paasela T, Švanys A, Tuohimetsä S, Peräniemi S, Tervahauta. 2003. Characterization of the glyoxalase 1 gene TcGLX1 in the metal hyperaccumulator plant. Thlaspi caerulescens. Planta 233:1173-1184 DOI 10.1007/s00425-011-1370-7.

Usui Y, Nakase M, Hotta H, Urisu A, Aoki N, Kitajima K, Matsuda T. 2001. A 33-kDa allergen from rice (Oryza sativa L. Japonica) cDNA cloning, expression, and identification as a novel glyoxalase I. Journal of Biological Chemistry 276:11376-11381 DOI 10.1074/jbc.M010337200.

Veena, Reddy VS, Sopory SK. 1999. Glyoxalase I from Brassica juncea: molecular cloning, regulation and its over-expression confer tolerance in transgenic tobacco under stress. The Plant Journal 17:385-395 DOI 10.1046/j.1365-313X.1999.00390.x.

Wahid A, Rao A, Rasul E. 1997. Identification of salt tolerance traits in sugarcane lines. Field Crops Research 54:9-17 DOI 10.1016/S0378-4290(97)00038-5.

Wu C, Ma CQ, Pan Y, Gong SL, Zhao CX, Chen SX, Li HY. 2013a. Sugar beet M14 glyoxalase I gene can enhance plant tolerance to abiotic stresses. Journal of Plant Research 126:415-425 DOI 10.1007/s10265-012-0532-4.

Wu QB, Xu LP, Guo JL, Su YC, Que YX. 2013b. Transcriptome profile analysis of sugarcane responses to Sporisorium scitaminea infection using Solexa sequencing technology. BioMed Research International DOI10.1155/2013/298920.

Yadav SK, Singla-Pareek SL, Ray M, Reddy MK, Sopory SK. 2005. Methylglyoxal levels in plants under salinity stress are dependent on glyoxalase I and glutathione. Biochemical \& Biophysical Research Communications 337:61-67 DOI 10.1016/j.bbrc.2005.08.263.

Yadav SK, Singla-Pareek SL, Reddy MK, Sopory SK. 2005. Methylglyoxal detoxification by glyoxalase system: a survival strategy during environmental stresses. Physiology \& Molecular Biology of Plants 11:1-11.

Yadav SK, Singla-Pareek SL, Kumar M, Pareek A, Saxena M, Sopory SK. 2007. Characterization and functional validation of glyoxalase II from rice. Protein expression \& purification 51:126-132. DOI 10.1016/j.pep.2006.07.007.

Yang YT, Fu ZW, Su YC, Zhang X, Li GY, Guo JL, Que YX, Xu LP. 2014. A cytosolic glucose-6-phosphate dehydrogenase gene, $S c G 6 P D H$, plays a positive role in response to various abiotic stresses in sugarcane. Scientific Reports 4:7090. DOI 10.1038/srep07090. 
623 Zeng ZM, Xiong FJ, Yu XH, Gong XP, Luo JT, Jiang YD, Kuang KC, Gao BJ, Niu XL, 624 Liu YS. 2016. Overexpression of a glyoxalase gene, OsGly I, improves abiotic stress 625 tolerance and grain yield in rice (Oryza sativa L.). Plant Physiology and Biochemistry, 109: 626 62-71. DOI: 10.1016/j.plaphy.2016.09.006.

627 Zarcinas BA, Pongsakul P, McLaughlin MJ, Cozens G. 2004. Heavy metals in soils and crops 628 in Southeast Asia 2. Thailand. Environmental Geochemistry \& Health. 26:359-371. DOI $629 \quad 10.1007 / \mathrm{s} 10653-005-4670-7$.

630

631

632 Table 1 Primers used in the present study

\begin{tabular}{lll}
\multicolumn{1}{c}{ Primer } & \multicolumn{1}{c}{ Sequence (5'-3') } & \multicolumn{1}{c}{ Application } \\
\hline G-F & AGCCAGAAGAAAGGGAGC & RT-PCR \\
G-R & GTTTCCGCCTTGATGAAC & \\
G-32aF & CGGAATTCATGGCAACTGGTAGTGAAG & Prokaryotic expression vector \\
G-32aR & CCCTCGAGTCAGTGAAGTTCCCTGAG & construction \\
\cline { 2 - 2 } G-QF & TGGACCGCACAATCAAATACTACAC & \\
G-QR & GTATGACATTGGAACGGGCTTTG & RT-qPCR \\
25S-QF & GCAGCCAAGCGTTCATAGC & \\
25S-QR & CCTATTGGTGGGTGAACAATCC &
\end{tabular}




\begin{tabular}{lll} 
GAPDH-QF & CACGGCCACTGGAAGCA & \\
GAPDH-QR & TCCTCAGGGTTCCTGATGCC & \\
PCX-GFP-F & ATGGTGAGCAAGGGCGAGGAG & $\begin{array}{l}\text { Fusion PCR primers for sub- } \\
\text { cellular localization }\end{array}$ \\
GLO-LAP1-R & ACTACCAGTTGCCATCTTGTACAGC & \\
GLO-LAP2-F & GCTGTACAAGATGGCAACTGGTAGT & \\
GLO-R & TCAGTGAAGTTCCCTGAGGAAGTCG & \\
\hline
\end{tabular}

633

634

635

636

637

638

639

640

641

642

643

644

645

646

647

648 


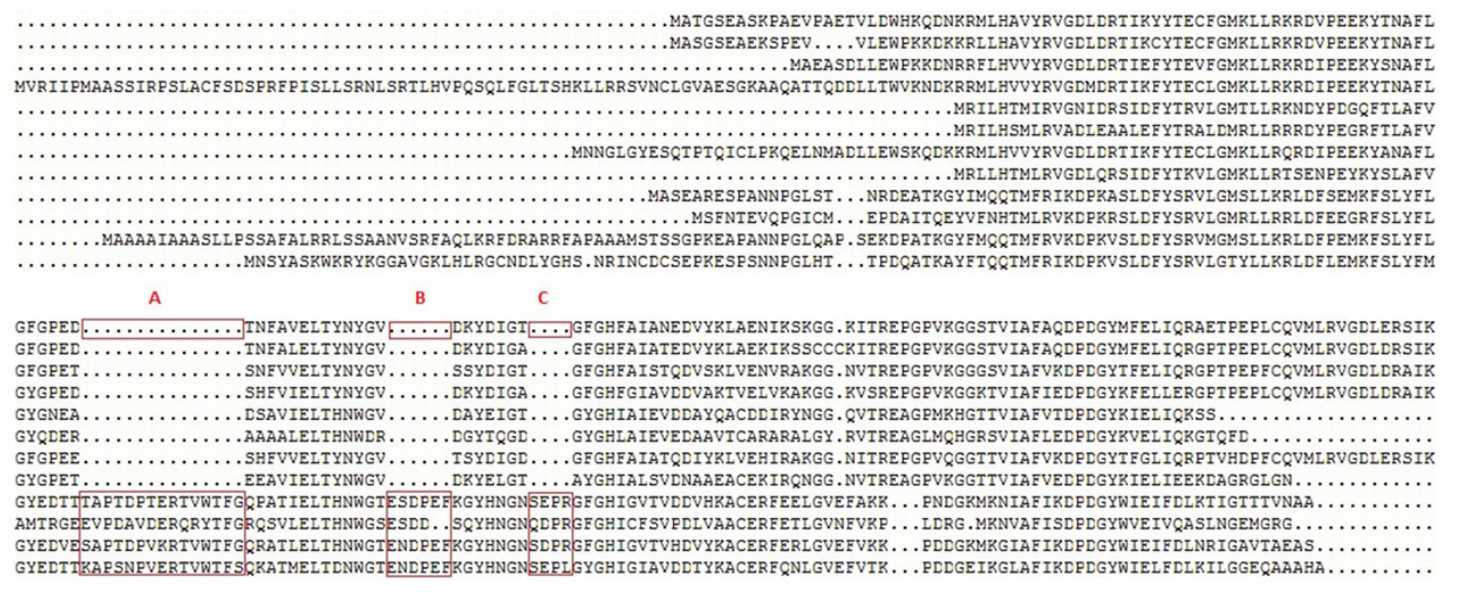

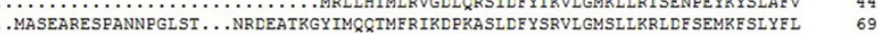

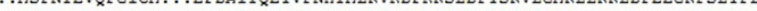
.................MSYASKWRRYRGGAVGRLHLRGCNDLYGHS. NRINCDCSEPRESPSNNPGLHT...TPDCATKAYFTQQTMFRIKDPRVSLDFYSRVLGTYLLRRLDFLEMRFSLYFM

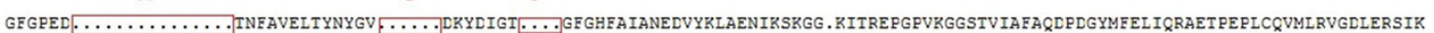
GFGED $\ldots \ldots \ldots \ldots \ldots$ TNFALELTYNYGV $\ldots \ldots \ldots$ DRYDIGA $\ldots \ldots$ GFGHFAIATEDVYRLAERIRSSCCCRITREPGPVRGGSTVIAFACDPDGYMFELICRGPTPEPLCCVMLRVGDLDRSSIR

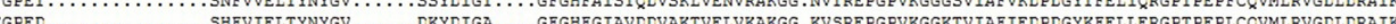
等 ................. (1)

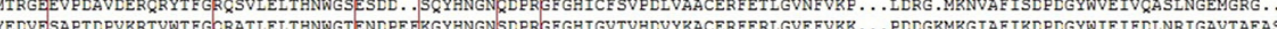

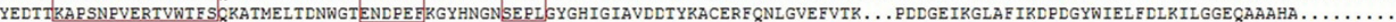

FYEKALGLKLLRKKDVPDYKYTIAMLGYADEDKTTVLELTYNYGVTEYSKGNAYAQVAIGTNDVYKSAEAVECATKELGGKILRQPGPLPGINTKIASFVDPDGWKVVLVDNTDFLREL FYEKALGMRLLRKKDVPDYKYTIAMLGYADEDKTTVIELTYNYGVTEYTRGNAYACVAIGIEDVYKSAEAVELVTKELGGKILRCFGPLPGLNTRIASFLDPDGWKVVLVDNADFLREL FYERALGMRLLRKIERPEYKYT IGMMGYAEEYESTVLELTYNYDVTEYTKGNAYACIAIGTDDVYRSGEVIRIVNCELGGRITREAGPL PGLGTRIVSFLDPDGWRTVLVDNKDFLREL FYEKAFGMELLRTRDNPEYRYT IAMMGYGPEDKF FVLELTYNYGVTEYDKGNAYACIAIGTDDVYKTAEAIRLF $\ldots$. GGRITREPGPLPGISTRITACLDPDGWRSVFVDNIDFLLKEL

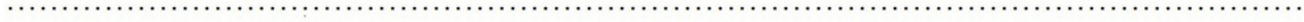

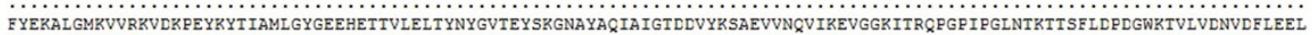

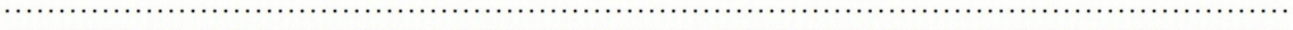

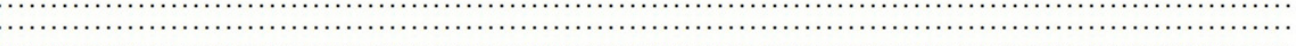

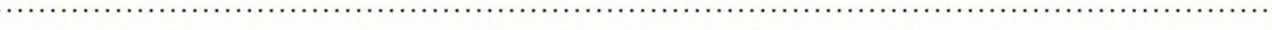

Figure 1 Multiple protein sequence alignment of SoGloI protein with glyoxalase I proteins from other species. The species name and accession numbers are as follows: Oryza sativa (OsglyI-11.2 and O. Zn-GloI with Acc. No. Os08g09250 and EEC78918.1), Arabidopsis thaliana (AtGLYI2, AtGLYI3 and AtGLYI6 with Acc. No. NP_172291.1, NP_172648.1, and NP_176896.1 respectively), Pseudomonas aeruginosa (GloA1, GloA2 and GloA3 with Acc. No. AAG06912, AAG04099 and AAG08496 respectively), Glycine max (G. Zn-GloI and G. Ni-GloI with Acc. No. XP_003539194.1 and XP_003528689.1) and Escherichia coli (GlxI with Acc. No. AAC27133). The letters $\mathrm{A}, \mathrm{B}$ and $\mathrm{C}$ represent extended sequences found in $\mathrm{Zn}^{2+}$-dependent GLOI, but absent in $\mathrm{Ni}^{2+}$-dependent GLOI. 


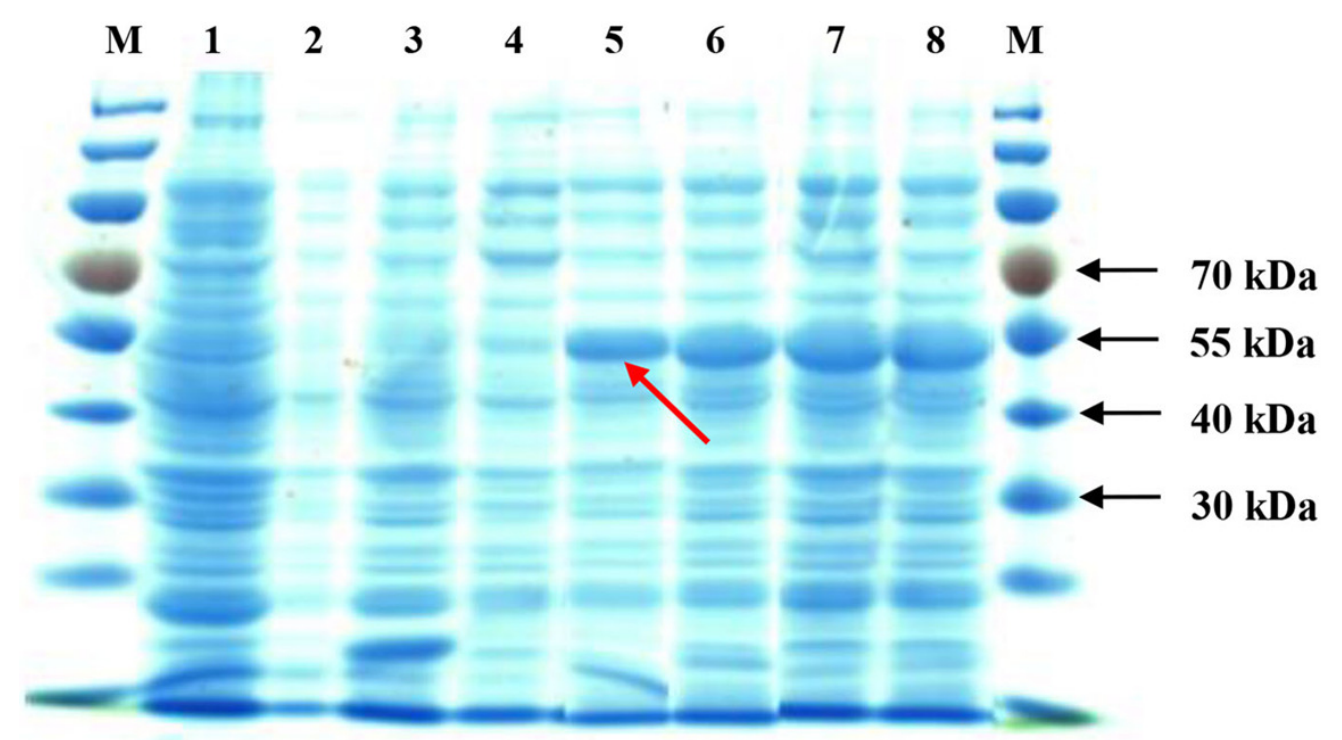

Figure 2 Heterologous expression of recombinant SoGloI in $E$. coli Rosetta cells (red arrow). Lane designation: $M$, protein size makers with 30, 40, 55, and $70 \mathrm{kDa}$ indicated; 1 , blank; 2, control without IPTG induction; 3, control with induction for $8 \mathrm{~h}$; 4, pET 32a-SoGloI without induction; 5 to 8 , pET32a-SoGloI with induction for 2, 4, 6 and 8 h, respectively. 


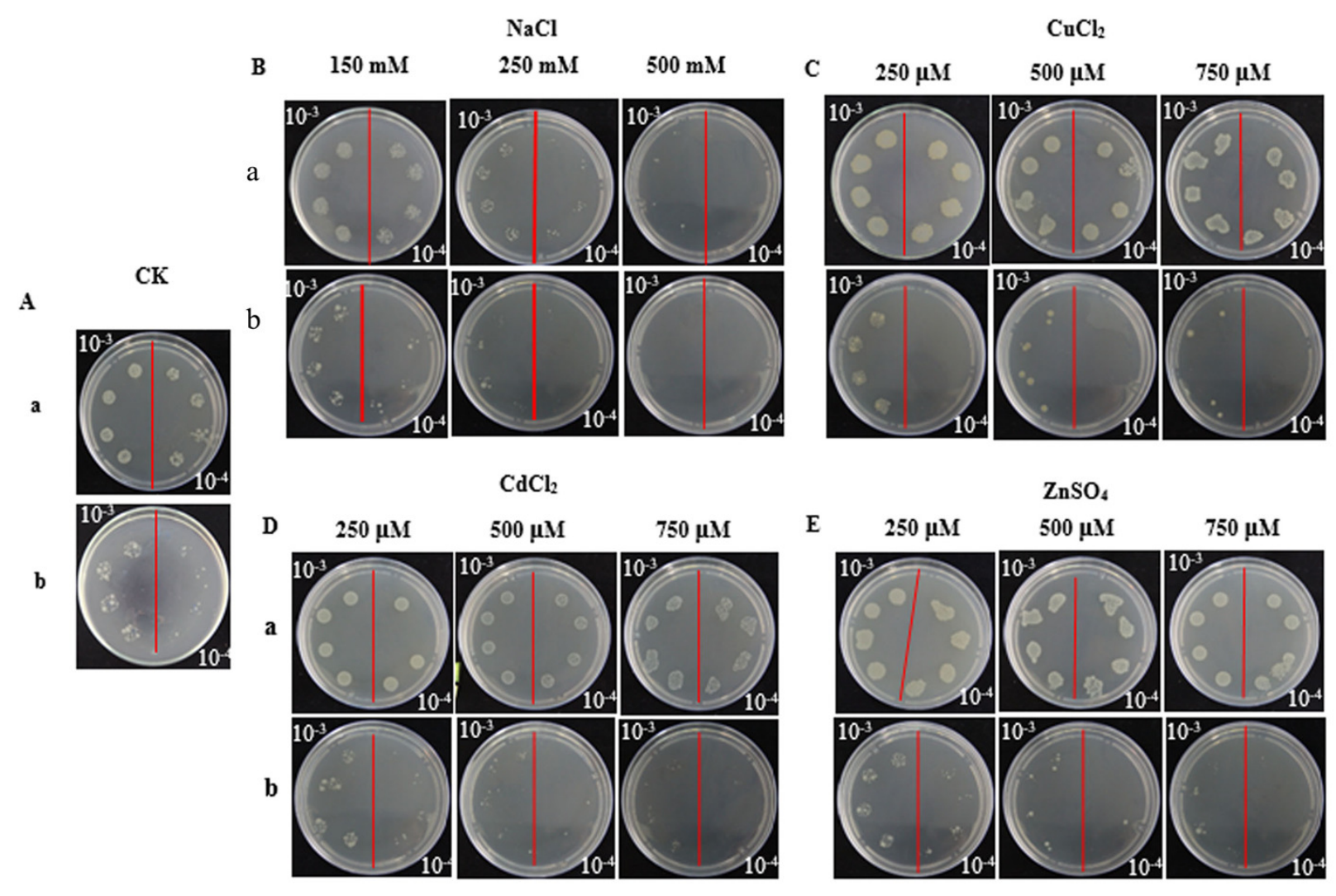

Figure 3 Growth of pET32a-SoGloI-expressing (row a) and pET 32a (row b) E. coli Rosetta cells on LB agar plates with various concentrations of salt or heavy metal ions indicated above the figures. Panel $3 \mathrm{~A}$, Control; Panels $3 \mathrm{~B}, \mathrm{NaCl} ; 3 \mathrm{C}, \mathrm{CuCl}_{2} ; 3 \mathrm{D}, \mathrm{CdCl}_{2}$, and $3 \mathrm{E}, \mathrm{ZnSO}_{4}$. 
A

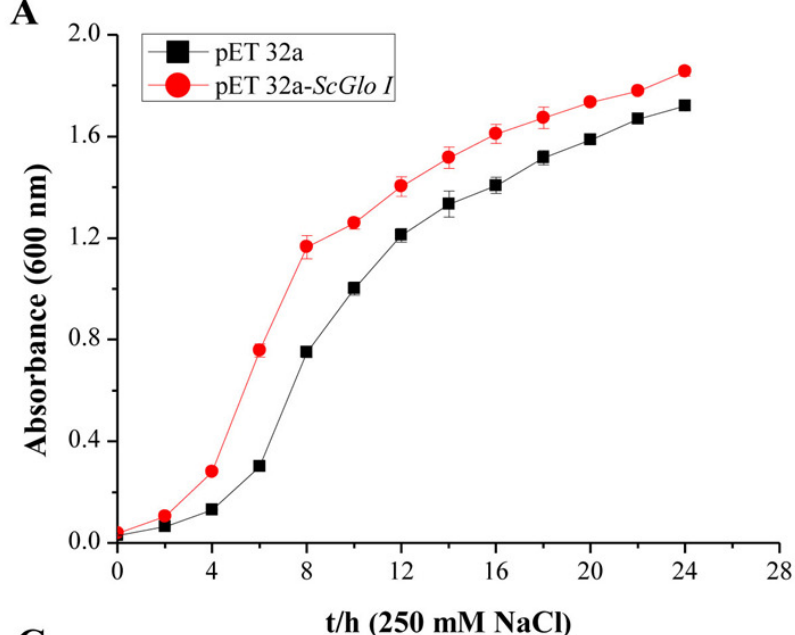

C

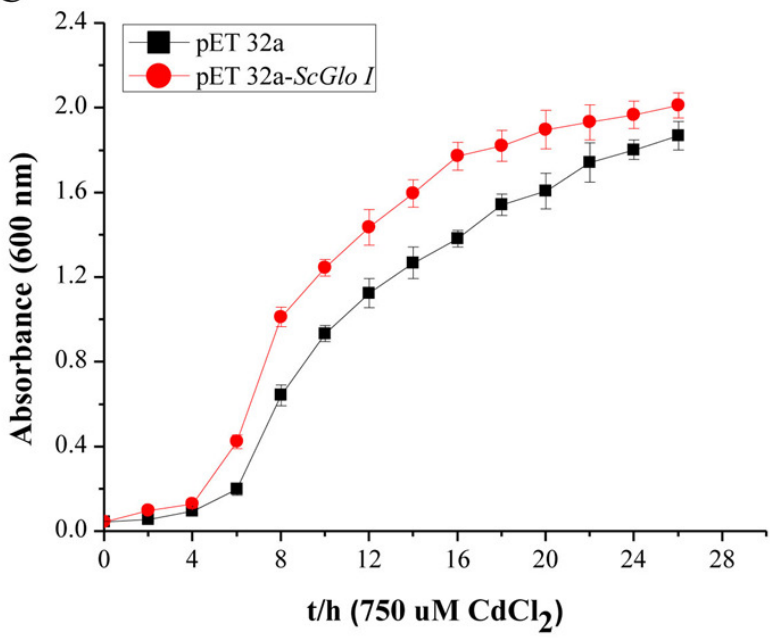

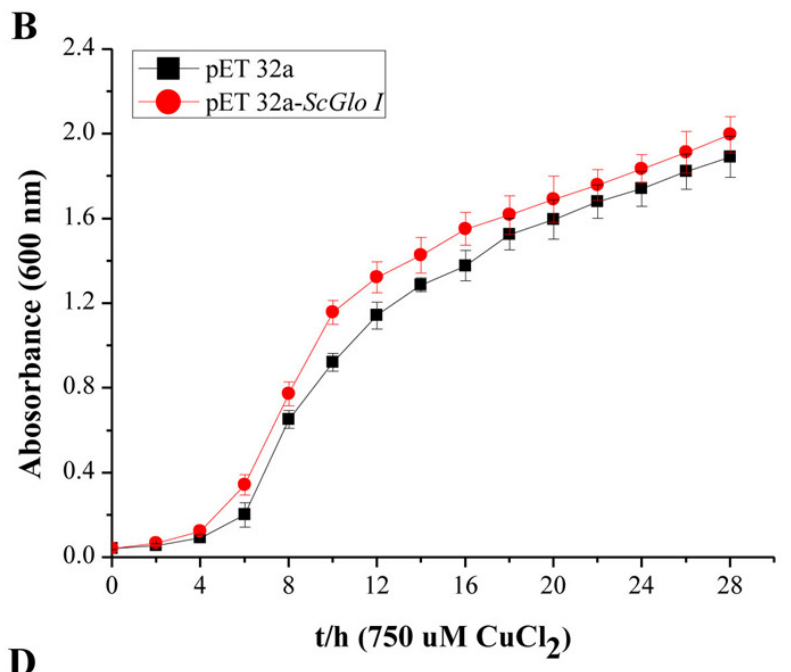

D

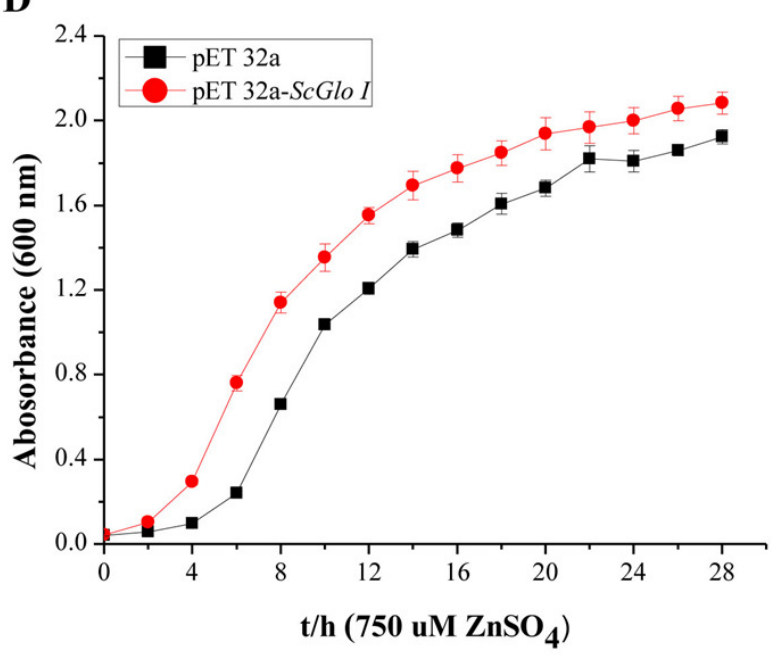

Figure 4 Growth assessments of SoGloI overexpressing $E$. coli cells under salt and heavy metal treatments.

Panel 4A, under $250 \mathrm{mM} \mathrm{NaCl}$ treatment from $0 \mathrm{~h}$ to $24 \mathrm{~h}$; Panel $4 \mathrm{~B}$, under $750 \mu \mathrm{M} \mathrm{CuCl}_{2}$ treatment from $0 \mathrm{~h}$ to $28 \mathrm{~h}$; Panel $4 \mathrm{C}$, under $750 \mu \mathrm{M} \mathrm{CdCl}_{2}$ treatment from $0 \mathrm{~h}$ to $26 \mathrm{~h}$; Panel 4D, under $750 \mu \mathrm{M} \mathrm{ZnSO} 4$ treatment from $0 \mathrm{~h}$ to $28 \mathrm{~h}$.

All data were measured every two hours. All data points are mean $\pm \operatorname{SE}(n=3)$. 

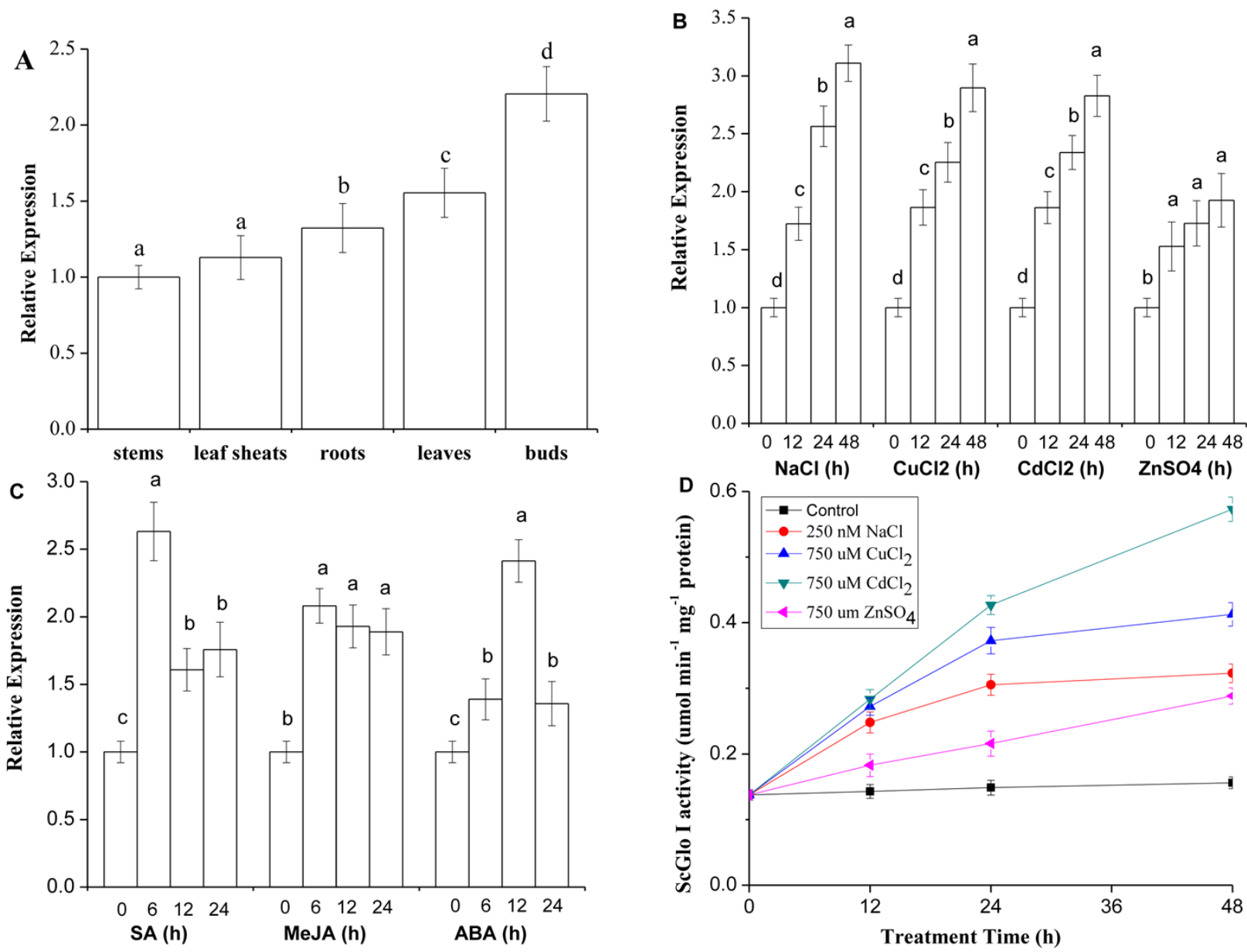

Figure 5 Expression patterns of SoGloI in sugarcane.

Panel 5A, SoGloI expression in different sugarcane tissues collected in the field; Panel 5B, SoGloI expression in greenhouse-grown sugarcane plantlets under $\mathrm{NaCl}, \mathrm{CuCl}_{2}, \mathrm{CdCl}_{2}$, and $\mathrm{ZnSO}_{4}$ treatments; Panel 5C, SoGloI expression in greenhouse-grown sugarcane plantlets under $\mathrm{SA}, \mathrm{MeJA}$, and ABA treatments; Panel 5D, glyoxalase I activity under $\mathrm{NaCl}, \mathrm{CuCl}_{2}, \mathrm{CdCl}_{2}$, and $\mathrm{ZnSO}_{4}$ treatments.

Different letters indicate a significant difference at 5\% level $(\mathrm{p} \leq 0.05)$. Each value represents the average of three biological repeats $\pm \operatorname{SE}(n=3)$. 


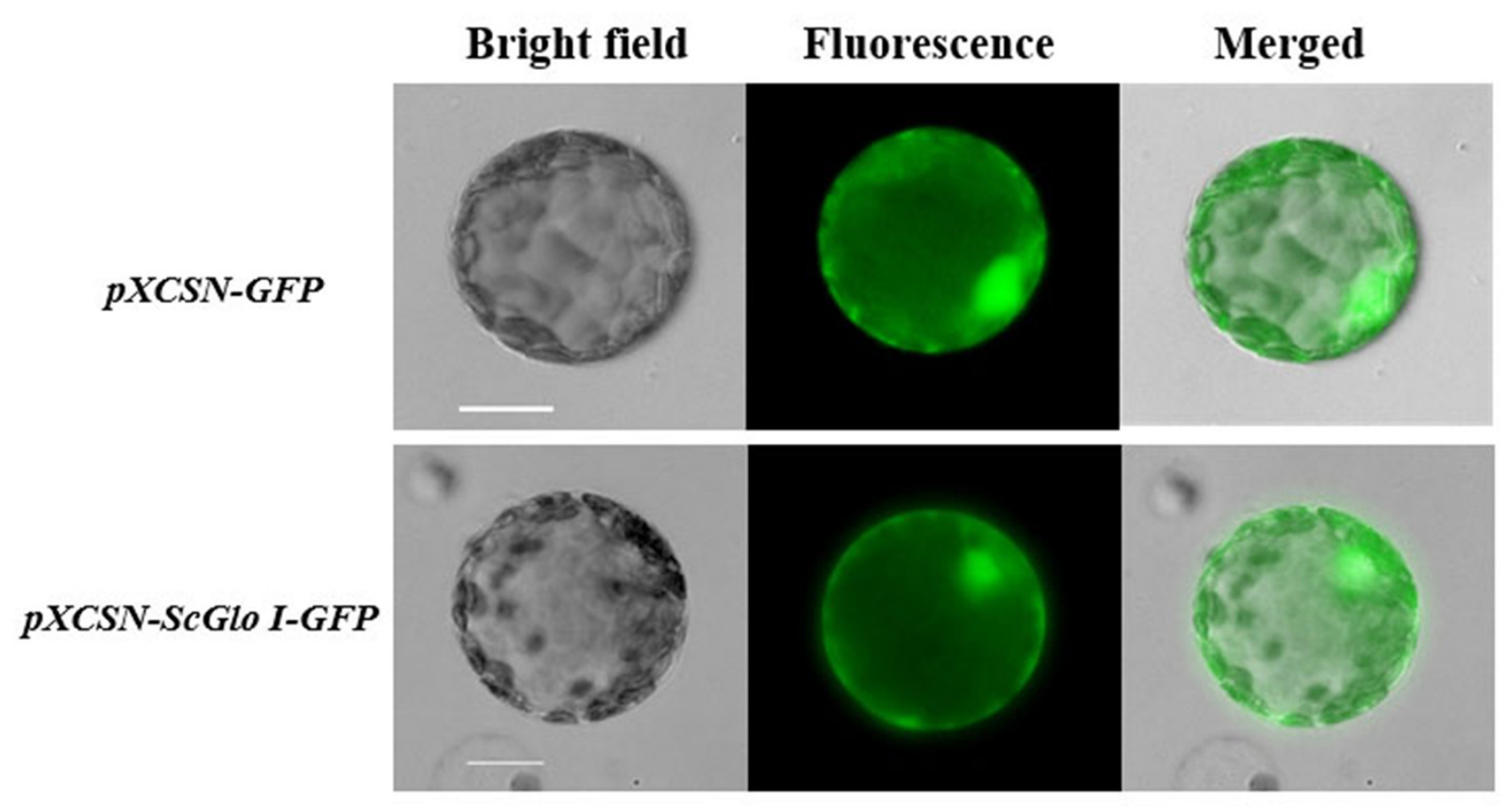

Figure 6 Determination of subcellular localization of ScGloI in tobacco (Nicotiana benthamiana) protoplasts under a fluorescence microscopy. The emission wavelength is 515 $\mathrm{nm}$ and the excitation wavelength is between $470 \mathrm{~nm}$ and $490 \mathrm{~nm}$. 